\title{
Numerical study of the October 2007 flash flood in the Valencia region (Eastern Spain): the role of orography
}

\author{
F. Pastor ${ }^{1}$, I. Gómez ${ }^{1}$, and M. J. Estrela ${ }^{2}$ \\ ${ }^{1}$ Laboratorio de Meteorología-Climatología, Unidad Mixta CEAM-UVEG, Fundación Centro de Estudios Ambientales \\ del Mediterráneo, Area de Meteorología-Climatología, Paterna, Valencia, Spain \\ ${ }^{2}$ Laboratorio de Meteorología-Climatología, Unidad Mixta CEAM-UVEG, Departament de Geografía Física, \\ Universitat de Valencia, Paterna, Valencia, Spain
}

Received: 8 July 2009 - Revised: 9 April 2010 - Accepted: 17 June 2010 - Published: 25 June 2010

\begin{abstract}
A torrential rain event took place in the Valencia region in October 2007, mainly affecting coastal areas and nearby mountains in the center-south of the region, in northern Alicante province. More than $400 \mathrm{~mm}$ in $24 \mathrm{~h}$ were recorded at some stations in these areas, with lower accumulations in the rest of the region where rainfall was less intense. In the first part of this work a description of the meteorological situation is given. The synoptic frame of the event is characterised by an advection of easterly maritime winds across the Western Mediterranean, lasting for at least $48 \mathrm{~h}$, driving moist air towards the Iberian Peninsula eastern coast and the presence of an upper level isolated low over Eastern Iberian Peninsula. Then, the results of numerical simulations using the Regional Atmospheric Modelling System model are shown to study the rain event in detail. The Regional Atmospheric Modelling System reproduces satisfactorily the spatial distribution of the rainfall and the rain period, but it underestimates precipitation in the areas with the most intense values. Finally, a sensitivity test was performed in order to evaluate the role of orography in the rain event, showing the importance of orography as a triggering mechanism.
\end{abstract}

\section{Introduction}

A flash-flood is defined in the AMS Glossary of Meteorology (Glickman, 2000) as a flood that rises and falls quite rapidly with little or no advance warning, usually as the result of intense rainfall over a relatively small area. Such flashfloods are common in the Mediterranean area and mostly occur from late summer to winter. The Valencia region

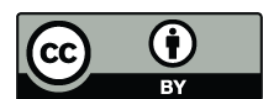

Correspondence to: F. Pastor (paco@ceam.es)
(Fig. 1), located in the Eastern Iberian Peninsula, has historically been affected by this type of heavy rain event (Elías and Ruiz, 1979; Armengot, 2002; Pérez Cueva and Armengot, 1983). This kind of meteorological event causes numerous economic losses, as well as human casualties in some cases. Moreover, several studies show an increasing trend in both the number of torrential rain events and their precipitation amounts (Alpert et al., 2002; Peñarrocha et al., 2002; Millán et al., 2005), and the Fourth Assessment Report of the Intergovernmental Panel on Climate Change (Solomon et al., 2007) also states that heavy-rain events are expected to be more frequent in most future-climate scenarios. Thus, a good knowledge about this type of event and about any improvement in its numerical modelling can be an invaluable aid for forecasting and alert systems.

Previous studies made clear that numerical modelling is crucial for understanding and forecasting of torrential rain events in the Mediterranean basin. First, the propitious environment for heavy rains in the Mediterranean basin has been extensively studied (Millán et al., 1995; Armengot, 2002; Estrela et al., 2002, 2003) while the statistical study in Jansa et al. (2001) correlate observations of heavy rains in the Western Mediterranean with the presence of surface cyclones. Numerous numerical modelling experiments on flash-floods have been conducted in this area in recent years. Some of these experiments have been focused on sensitivity testing (Federico et al., 2008; Bresson et al., 2009), development of forecasting systems (Davolio et al., 2009), air-sea interaction processes (Pastor et al., 2001; Lebeaupin et al., 2006, 2009) or investigation of the mechanisms involved in heavy rain events (Miglietta and Regano, 2008).

The Spanish eastern coast, and other areas in the Western Mediterranean basin, are often affected by northeasterly to southeasterly advections with trajectories over the Mediterranean sea, which we consider to be examples of backdoor

Published by Copernicus Publications on behalf of the European Geosciences Union. 


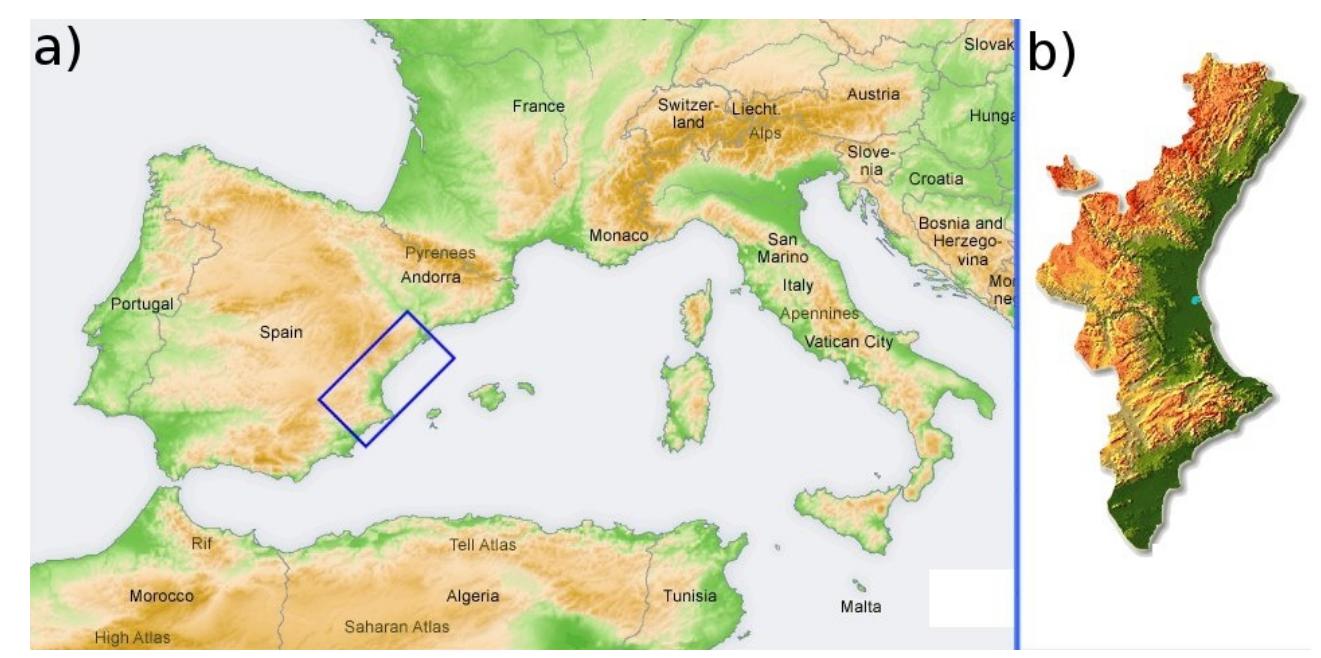

Fig. 1. The Valencia region in the Mediterranean area: (a) location, (b) orography.

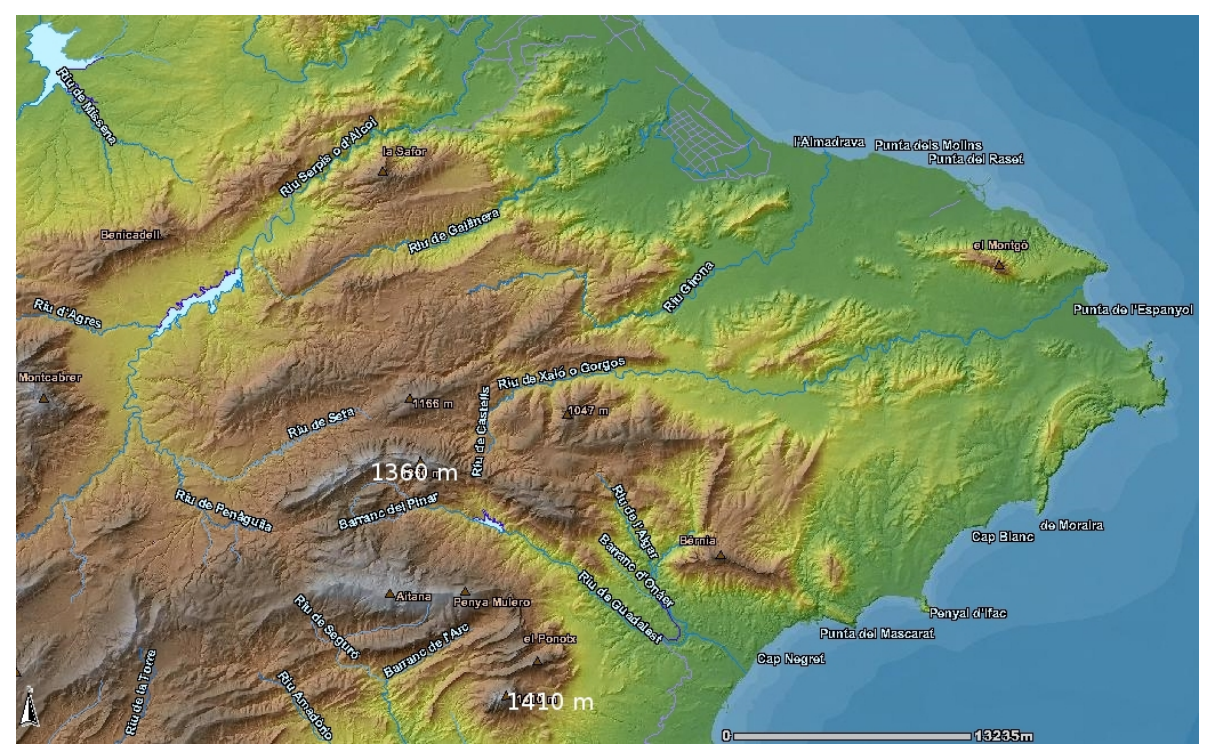

Fig. 2. Northern Alicante province orography. Highest peaks are on the southern side of the study area, reaching 1410 and $1558 \mathrm{~m}$. Courtesy of Conselleria de Medi Ambient, Aigua, Urbanisme i Habitatge de la Generalitat Valenciana.

(cold) fronts as defined in Bluestein (1993), understood as a cold(er) air advection over a warm(er) Mediterranean sea. The Valencia region is also affected by these advections which drive moist air from the Mediterranean, in some cases with long trajectories, and cause torrential rains. Some of the authors have previously studied the synoptic patterns and spatial rainfall distribution of these events in the Valencia region (Peñarrocha et al., 2002) as well as the relative contribution of these torrential rains to the total rainfall in the area (Millán et al., 2005).

The highest pluviosity in the Valencia region is registered in the northeastern part of Alicante province, located south of the Gulf of Valencia. The analysis by Romero et al. (1998) of a 30-year rainfall precipitation series covering the Spanish Mediterranean coast showed the notable impact of torrential rains in the Valencia region in particular in the northeastern area of Alicante province (Sierra de Aitana). The orography of this area (Fig. 2) is constituted by a narrow coastal strip and various mountain ranges, between 300 and $700 \mathrm{~m}$ high, close to the coast and mostly running from southwest to northeast. These mountain ranges separate a series of long, narrow valleys, open to the coast and closed inland by higher mountains (more than $1000 \mathrm{~m}$ tall), which are very well exposed to the northeastern or eastern maritime air advections. These moist maritime air fluxes are the main precipitation input in this area both in intensity and in annual values (Peñarrocha et al., 2002; Millán et al., 2005). Annual 
total precipitation averages in this area are always higher than $650 \mathrm{~mm}$ with some sections registering more than $900 \mathrm{~mm}$, resulting in a subhumid climate. Pluviosity in the Northeast of the province of Alicante is characterized by high irregularity with a high percentage of the total annual rain concentrated in a few precipitating days, e.g., 750 precipitation values higher than $100 \mathrm{~mm} /$ day have been found from 1943 to 2008 in the meteorological stations database of the Spanish Meteorological Agency (AEMET), with 112 records reaching or exceeding $200 \mathrm{~mm} /$ day. A historical maximum of $878 \mathrm{~mm}$ was recorded on 2 October 1957 at Xabia station. Annual rainfall distribution is characterized by a relatively dry summer and two wet periods in spring and autumn, with autumn providing the most rain and exceeding by far the rain accumulation in spring (Pérez Cueva, 1994).

In this work, the authors present a description of an extraordinary rain event through analysis of synoptic setting and surface data, mainly on precipitation. Then the Regional Atmospheric Modelling System (RAMS) is used to investigate the main characteristics of the torrential rains in the study area, focusing on the mechanisms feeding the precipitating system, especially the presence of strong and constant maritime winds that allow the intense precipitation to persist. After characterizing the rain event we evaluated the role of orography in its development, showing its importance in triggering the rainfall event. The role of orography in heavy rain events in the Western Mediterranean has previously been investigated in papers by Romero et al. (1997), Horvath et al. (2006), Federico et al. (2008), and Miglietta and Regano (2008).

\section{Meteorological analysis}

\subsection{Synoptic analysis}

The synoptic frame of the meteorological situation leading to the torrential rains of 11-12 October 2007 in the Valencia region was characterized by an easterly maritime wind advection across the Western Mediterranean, lasting for at least $48 \mathrm{~h}$ and reaching the east side of Iberian Peninsula, and by the presence of an upper-level isolated low over the Eastern Iberian Peninsula. This long-trajectory advection resulted in the arrival of a moist air mass over the Valencia region which, in conjunction with the presence of a cold pool aloft, caused the torrential rains. There follows a description of the meteorological situation on the days previous to and during the event.

Figure 3 shows the sea level pressure and geopotential height of the $500 \mathrm{hPa}$ isosurface from NCEP/NCAR Reanalysis (Kalnay and Coauthors, 1996). During 9-10 October 2007 an upper-level cold air pool above northwestern France and south of the British Isles started moving southward, allowing the irruption of a strong anticyclonic ridge towards Northern Europe. This isolated upper-level low reached

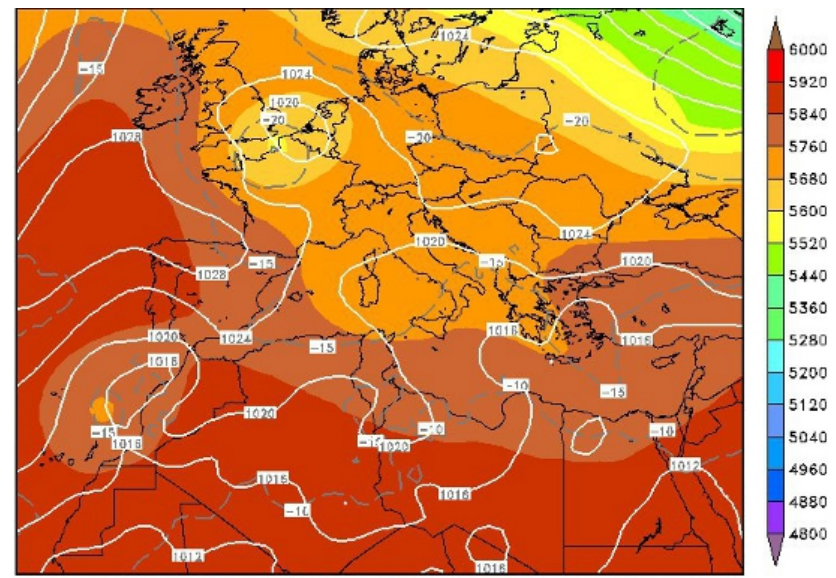

(a)

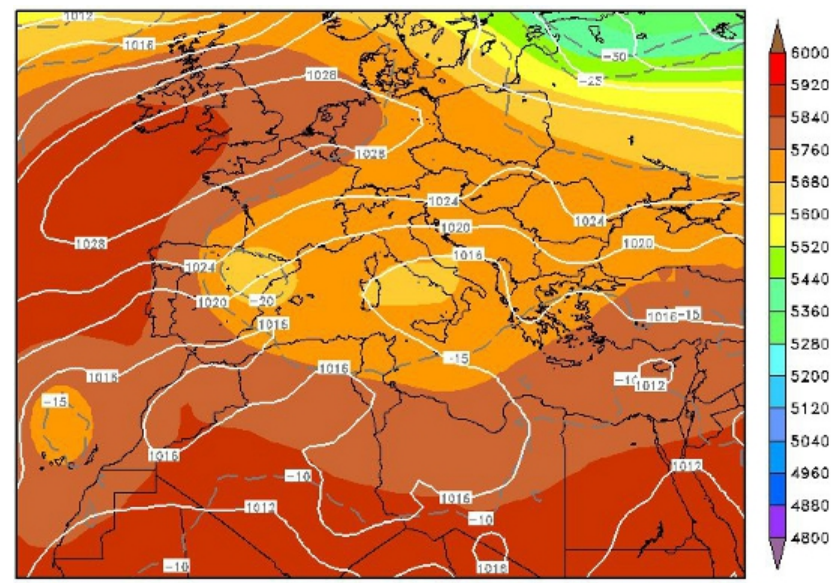

(b)

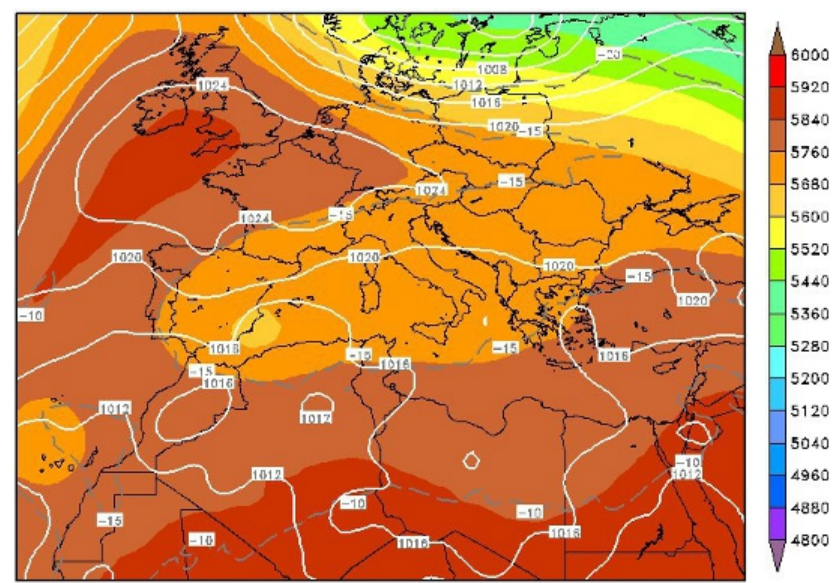

(c)

Fig. 3. Sea level pressure ( $\mathrm{hPa}$, solid line), geopotential height (gpm, shaded color) and temperature in ${ }^{\circ} \mathrm{C}$ (dashed line) at $500 \mathrm{hPa}$ on (a) 10 October 2007 at 00:00 UTC, (b) 11 October 2007 at 00:00 UTC and (c) 12 October 2007 at 00:00 UTC, obtained from NCEP Reanalysis. 

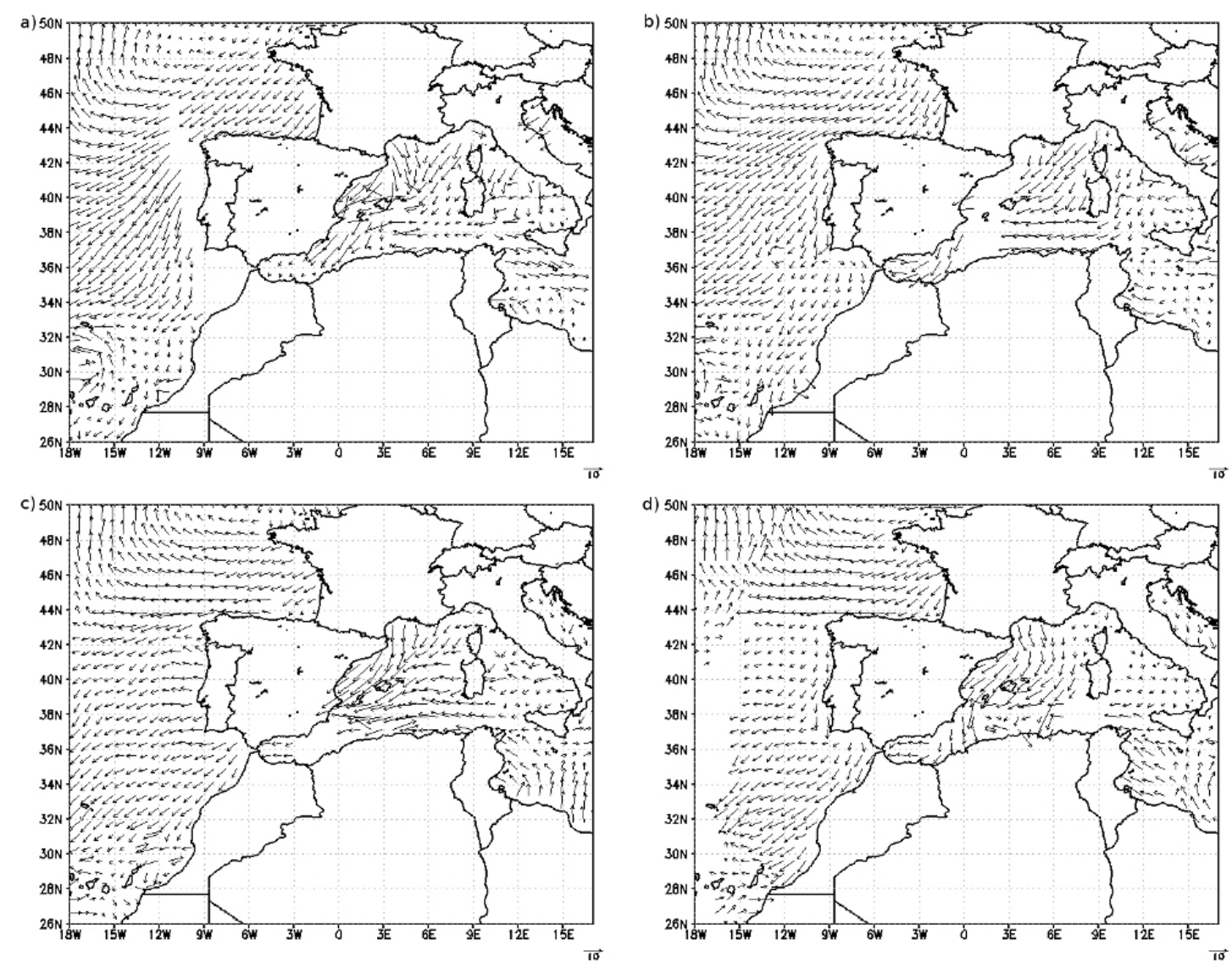

Fig. 4. Surface winds at (a) 06:00 UTC 11 October, (b) 18:00 UTC 11 October, (c) 06:00 UTC 12 October and (d) 18:00 UTC 12 October 2007. Quickscat Seawind data courtesy of Remote Sensing Systems.

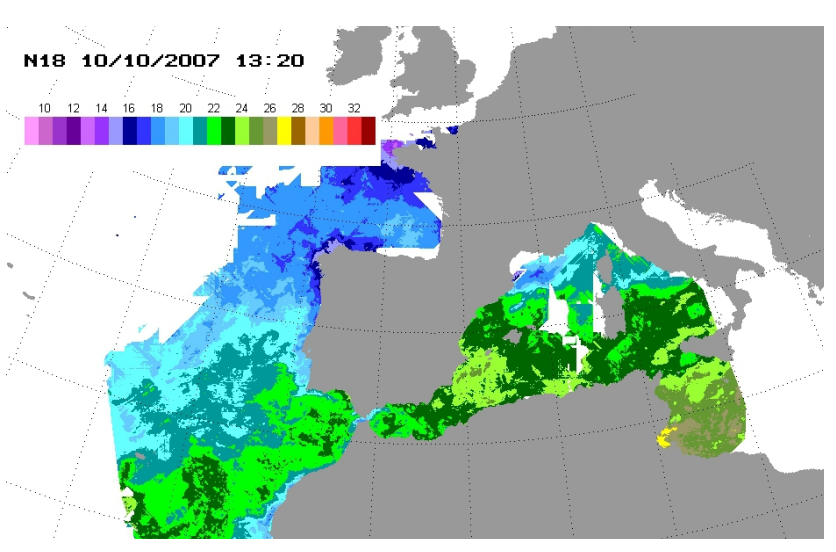

Fig. 5. Sea surface temperature $\left({ }^{\circ} \mathrm{C}\right)$ on 10 October 2007 derived from the NOAA satellite by the CEAM meteorology department.

eastern Iberia and became situated just above the vertical of the Valencia region on 11 October. The presence of an air mass with temperatures below $-20^{\circ} \mathrm{C}$ added strong instability at middle and upper levels in the Valencia region on 11 and 12 October (Fig. 3).
At surface level a strong anticyclone remained stationary over most of Western and Northern Europe. Along the southern side of these high pressures, an easterly wind flowed from Central-Eastern Europe over the Western Mediterranean, reaching the Valencia region (Fig. 4). The initially colder and drier air-mass driven by this easterly advection became moist and potentially unstable because of the energy and moisture exchanges between the atmosphere and a warmer Mediterranean sea (Millán et al., 1995; Estrela et al., 2003) with temperatures in the $23-25^{\circ} \mathrm{C}$ range in broad parts of its Western basin (Fig. 5).

Then, an easterly flux of moist and "potentially unstable" air across the Mediterranean towards the Iberian Peninsula converged on the Valencia region, especially northern $\mathrm{Al}-$ icante. Both the presence of instability at middle and upper levels and the orographic trigger created an environment favourable for a heavy rain event.

On 11 and 12 October 2007, maritime easterly winds swept the Valencia region from north to south. From Fundación Centro de Estudios Ambientales del Mediterráneo (CEAM) meteorological network data it can be seen that precipitation started on the morning of 11 October in the north of the Valencia region and later extended to its southern half. 


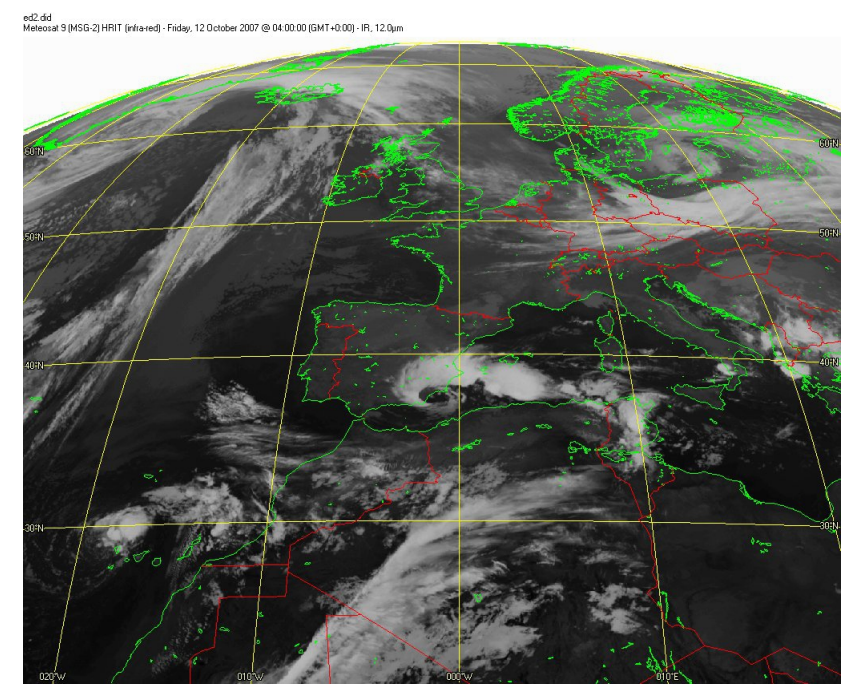

Fig. 6. MSG-2 Infrared image on 12 October 2007 at 04:00:00 UTC, (CEumetsat.

The persistence of the maritime winds, turning locally from east to northeast, formed a low level jet at low and mid levels which remained constant before, during, and after the rain event. The moisture content of the winds helped to establish a cloud system (Fig. 6) that affected the southern half of the Valencia region for $12-14 \mathrm{~h}$ and continuously fed the intense and persistent rains recorded in the area. Proper exposure of the coastal valleys and mountain regions to the northeasterly winds favoured the channeling of the air fluxes up the watersheds where the most intense and persistent rains were recorded.

\subsection{Surface data}

CEAM owns and operates a network of meteorological stations and fog collectors, equipped with meteorological sensors, covering the whole Valencia region. The network consists of 44 measuring points distributed throughout the Valencia region (14 on the heaviest rain area) from the coastal plains to the mountain areas inland, all of which are located away from urban environments and follow the WMO specifications for meteorological measurements. In addition to the data from this network, data from AEMET (25 in the Valencia region with 13 in the main rain area), the hydraulic authorities of the Confederación Hidrográfica del Júcar (CHJ) (36 stations in the rain area) and the Ministry of Agriculture (45 stations in the Valencia region, 27 of them in the rain area) have been also used in the characterization of the event. Figure 7 shows the rainfall spatial distribution map constructed from all the recorded data. This precipitation map shows a relatively wide region with precipitation greater than $100 \mathrm{~mm}$ around a highly focalized area of maximum precipitation, surpassing $300 \mathrm{~mm}$, in northeastern Alicante, especially over the mountain ranges close to the coast.
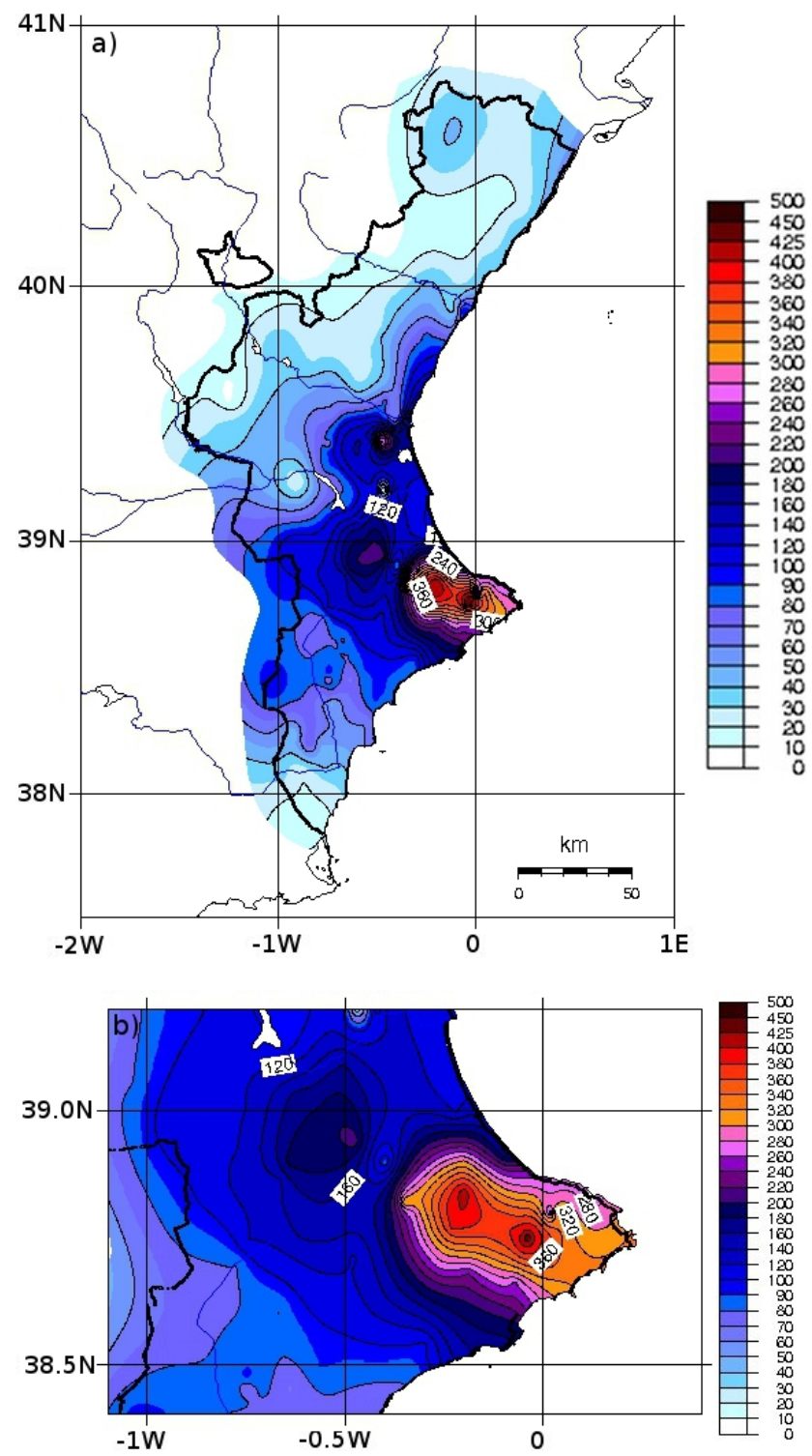

Fig. 7. 48-h accumulated precipitation (mm) during 11-12 October 2007: (a) Valencia region, (b) northeastern Alicante. Data recorded by CEAM Meteorology Department, AEMET and Confederación Hidrográfica del Júcar.

The stations with the highest accumulated values are shown in Table 1, while their locations are shown in Fig. 8. Table 1 and the stations location map again highlight the intensity and focalization of the rain event. Two automatic stations in the Fundación CEAM network have been selected to show the intensity of the rain event. Figure 8 shows the rain intensity (precipitation recorded in $10 \mathrm{~min}$ ) during the event at the Tollos and Callosa d'En Sarriá stations. The maximum intensity recorded at the first one was close to $90 \mathrm{~mm} / \mathrm{h}$ while at the second it barely reached $50 \mathrm{~mm} / \mathrm{h}$. Rainfall in the study area is seen to start late in the day on 11 October, with most rain falling during the first half of 12 October. Worthy 
Table 1. 48-h accumulated precipitation $(\mathrm{mm})$ from 00:00 UTC 11 October to 00:00 UTC 13 October 2007.

\begin{tabular}{llrll}
\hline & \multicolumn{4}{c}{ Accumulated precipitation (mm) } \\
Station & Acronym & 11 Oct & 12 Oct & Total \\
& & 2007 & 2007 & \\
\hline Alcalalí & ALC & 22.0 & 415.6 & 437.6 \\
Gallinera & GAL & 15.2 & 398.0 & 413.2 \\
Tollos & TOL & 25.6 & 359.8 & 385.4 \\
Isbert & ISB & 14.4 & 365.2 & 379.6 \\
Benissa & BSA & 181.0 & 154.0 & 335.0 \\
Beniarrés & BEN & 18.8 & 296.4 & 315.2 \\
Abdet & ABD & 12.0 & 262.6 & 274.6 \\
Marina Baixa & MAR & 11.0 & 245.8 & 256.8 \\
Callosa d'En Sarriá & CAL & 18.0 & 236.6 & 254.6 \\
Guadalest & GUA & 8.0 & 230.4 & 238.4 \\
Xátiva & XAT & 16.8 & 169.2 & 186.0 \\
Sierra Helada & SIE & 9.0 & 170.4 & 179.4 \\
Alfás del Pi & ALF & 15.3 & 154.8 & 170.1 \\
\hline
\end{tabular}

of note are not only the accumulated precipitation values, but also their intensity and persistence. Remarkable cases are the Alcalalí and Gallinera stations which exceeded $400 \mathrm{~mm}$ in 14 to $16 \mathrm{~h}$. Seven other stations also recorded values greater than $200 \mathrm{~mm}$, three of which were over $300 \mathrm{~mm}$. It should be noted that, at all stations, most of the precipitation was recorded during the dawn and early morning of 12 October.

\section{Numerical modelling}

\subsection{RAMS Model}

The non-hydrostatic version of the Regional Atmospheric Modelling System (RAMS), in its version 6.0, has been used to carry out the numerical experiments in this study. Extensive information about RAMS can be found in Pielke et al. (1992) and Cotton et al. (2003). RAMS has previously been used by researchers at Fundación CEAM in the Valencia region to determine the optimal configuration of the model (Salvador et al., 1999), to study the effects of sea surface temperature on torrential rains (Pastor et al., 2001), to study air pollution dispersion (Palau et al., 2005; Pérez-Landa et al., 2007a,b) and to forecast heat waves (Estrela et al., 2007) in the Valencia region. RAMS has also been used in the study of torrential rains in the Mediterranean area by other authors like Meneguzzo et al. $(2000,2001,2004)$ and Federico et al. (2008).

In this study we have performed two different simulations of the event; the first is the control run (CTRL), aimed at evaluating the performance of the model while the second (NOORO1) is performed to investigate the role of local orography in the model results by removing orography in the area within grid 4 . In both simulations, RAMS model was set
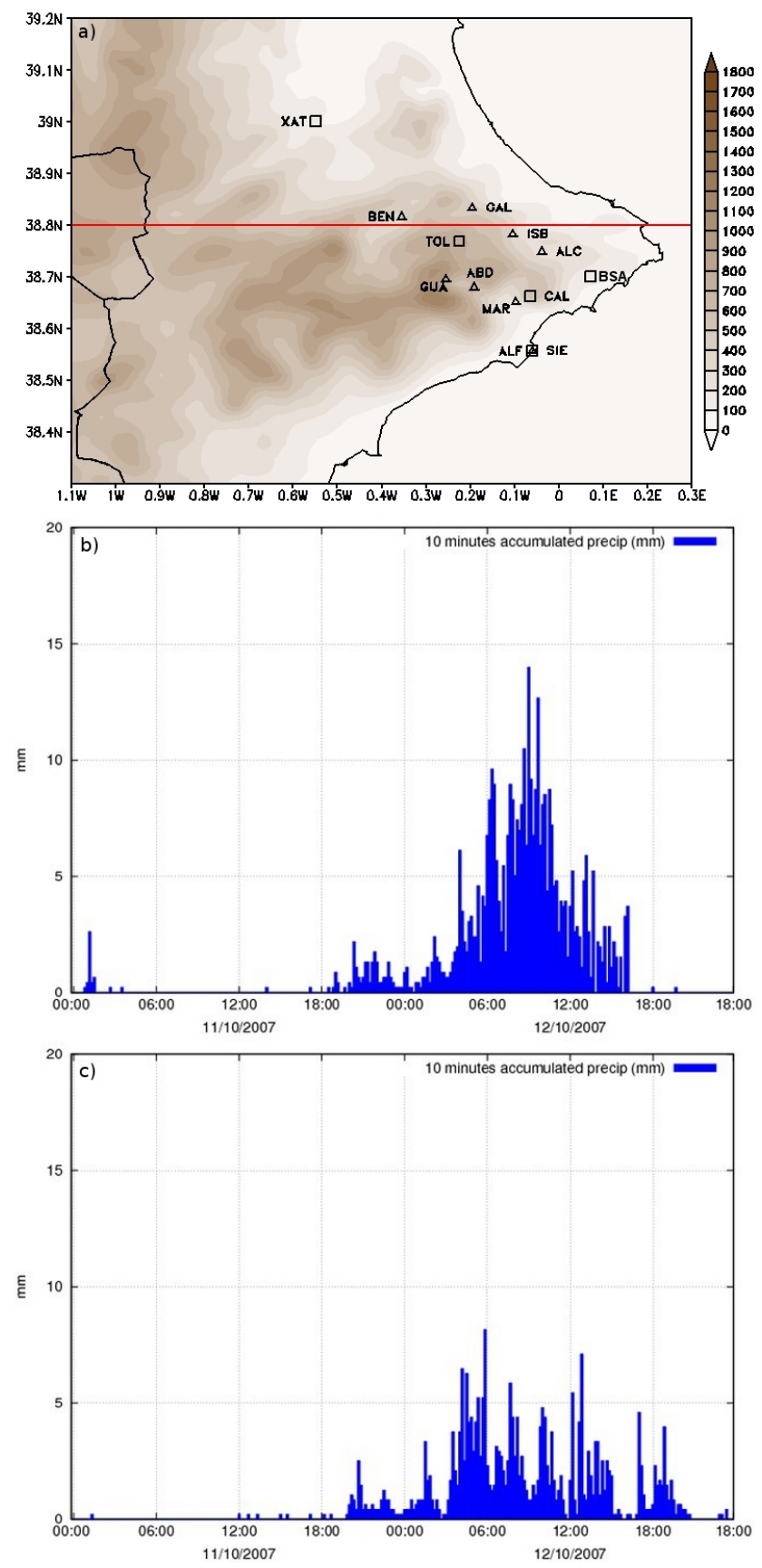

Fig. 8. (a) Location of the meteorological stations in Table 1 and location of vertical cross sections on RAMS grid 4. (b) Precipitation intensity (mm/10 min) during 11-12 October 2007 measured by CEAM Meteorology department meteorological network at Tollos (TOL) and (c) at Callosa d'En Sarriá (CAL) stations.

up with four domains of decreasing size at increasing spatial resolution. A series of two-way interactive nested domains were configured at grid spacings of 40.5, 13.5, 4.5, and $1.5 \mathrm{~km}$, respectively (Fig. 9). The vertical discretization is a 45 -level stretched vertical coordinate with a $30 \mathrm{~m}$ spacing near the surface increasing gradually up to $1000 \mathrm{~m}$ near 
the model top, at about $17000 \mathrm{~m}$, and with 15 levels in the lower $1000 \mathrm{~m}$. A summary of the grid parameters is provided in Table 2. RAMS includes the Mellor and Yamada (1982) level 2.5 turbulence parameterization, a full-column twostream single-band radiation scheme that accounts for clouds to calculate short-wave and long-wave radiation (Chen and Cotton, 1983) and a Kuo-modified parameterization of subgrid scale convection processes in the three outer domains (Molinari, 1985), whereas grid 4 utilizes explicit convection only. The cloud and precipitation microphysics scheme from Walko et al. (1995) was applied in all the domains.

Atmospheric boundary and initial conditions are derived from the National Centre for Environmental Prediction (NCEP) Global Final Analyses (FNL), available every $6 \mathrm{~h}$ at $1 \times 1$ degree resolution. A Four-Dimensional Data Assimilation (FDDA) technique is used to define the forcing at the lateral boundaries of the five outermost grid cells of the largest domain. Surface boundary conditions include USGS land cover dataset (Anderson et al., 1976). The LEAF-2 soilvegetation surface scheme is used to calculate sensible and latent heat flux exchanges with the atmosphere, using prognostic equations for soil moisture and temperature (Walko et al., 2000). For simplicity, we have prescribed LEAF-2 with a homogeneous soil texture of the clay-loam type. The soil column at each grid point is subdivided into 11 layers down to a depth of $2 \mathrm{~m}$. The soil moisture was initialized with a uniform profile at a value of $0.38 \mathrm{~m}^{3}$ of water per $\mathrm{m}^{3}$ of total volume. The initial soil temperature profile is obtained by subtracting from the surface air temperature a value of $2.3^{\circ} \mathrm{C}$ in the top soil, which linearly decreases down to a decrease of $1{ }^{\circ} \mathrm{C}$ in the bottom soil (Pérez-Landa et al., 2007b). Over the ocean, we prescribe the sea surface temperature climatological dataset provided by RAMS.

As the rain event took place from the final hours of 11 October to the first half of 12 October our simulation lasts for $48 \mathrm{~h}$, starting at 00:00 UTC on 11 October 2007 and finishing at 00:00 UTC on 13 October. Model results are saved every hour at the four grids and at all levels for the two days of the simulation.

\subsection{Modelling results}

\subsubsection{Control run}

As explained previously in Sect. 2.1, the general environment of the rain event was constituted by an easterly advection and the presence of a cold air pool above the Eastern Iberian Peninsula. These settings are well captured by grid 1 (Fig. 9) of the RAMS model for both simulations, as can be seen in Figs. 10 and 11 for the control simulation. The upper-level low moved southward over the Eastern Iberian Peninsula from the northern area where it was initially located at 00:00 UTC 11 October, arriving at the vertical of northern Alicante at 12:00 UTC, 11 October. It remained stationary at this position during the following night

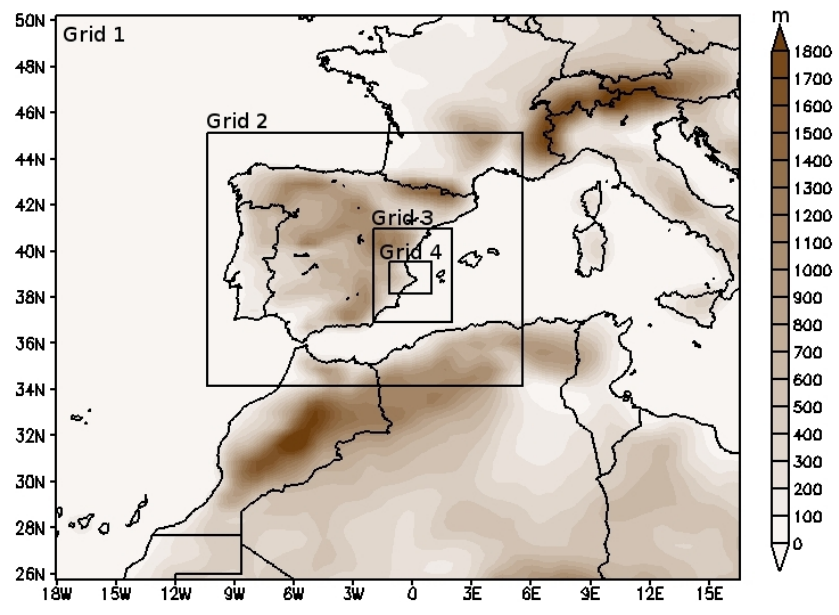

Fig. 9. RAMS model domains (all simulations) and orography (Control run) in $\mathrm{m}$.

Table 2. Rams model settings.

\begin{tabular}{lrrrrr}
\hline Grid & \multicolumn{1}{c}{$\mathrm{nx}$} & $\mathrm{ny}$ & $\mathrm{nz}$ & $\mathrm{dx}(\mathrm{m})$ & $\mathrm{t}(\mathrm{s})$ \\
\hline 1 & 90 & 80 & 45 & 40500 & 60 \\
2 & 110 & 101 & 45 & 13500 & 30 \\
3 & 83 & 101 & 45 & 4500 & 15 \\
4 & 128 & 101 & 45 & 1500 & 5 \\
\hline
\end{tabular}

when the torrential rains took place. In RAMS results, the low slightly moves to the south of its actual position during the night, arriving over the Mediterranean and slowly dissipating some hours before the actual evolution of the low (see Fig. 3). In the coarser grid (grid 1) RAMS correctly captures the easterly-northeasterly low level flow across the Western Mediterranean towards the Eastern Spanish coast, checked against QuickScat seawinds (Fig. 4). Winds reaching the Valencia region and specifically the rainy area in the northern part of Alicante province are mostly from the northeast.

Figure 12 shows the surface wind field during the rain period every $6 \mathrm{~h}$ from 18:00 UTC 11 October 2007 to 12:00 UTC 12 October 2007. These wind maps clearly show the entry of sea winds with an easterly and, mostly, northeasterly component. At 18:00 UTC on 11 October, offshore winds are from the east, coastal winds to the north of the rain area are from the northeast and winds inland show no clear organization, with weak northerly to westerly winds, the latter on the coastal areas. $6 \mathrm{~h}$ later, at 00:00 UTC on 12 October, easterly winds become generalized along the coast and, although weaker than offshore, start to penetrate inland. During the following hours the easterly winds become stronger and turn northeasterly, thus affecting not just the coast but the coastal strip and the first mountain barriers inland. This situation lasts most of the day, as can be seen in Fig. 12. 

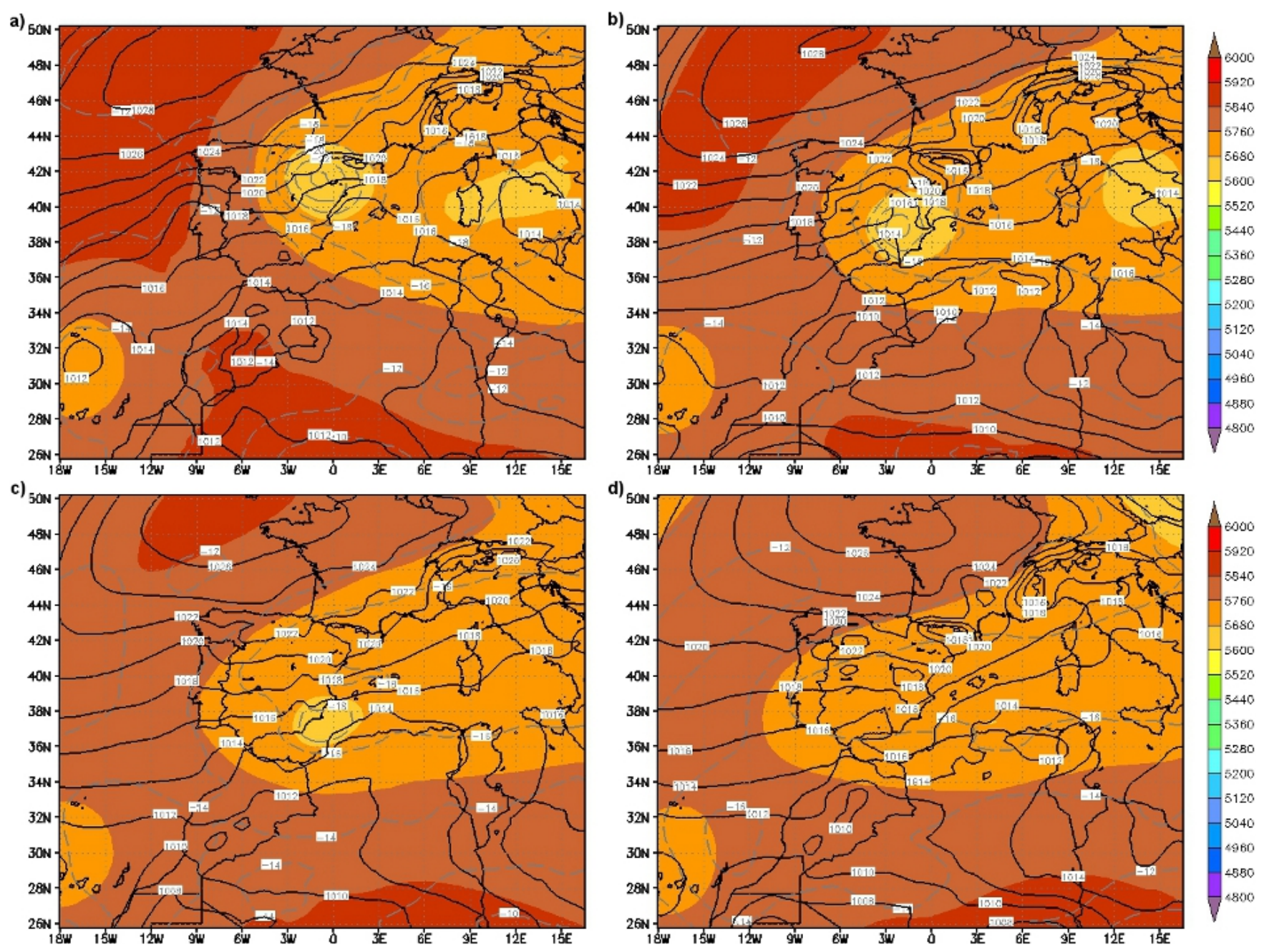

Fig. 10. RAMS model sea level pressure (hPa, solid line), temperature $\left({ }^{\circ} \mathrm{C}\right.$, dashed line) and geopotential height in (gpm, shaded color) at $500 \mathrm{hPa}$ for the control simulation at (a) 00:00 UTC 11 October, (b) 12:00 UTC 11 October, (c) 00:00 UTC 12 October, (d) 12:00 UTC 12 October.

There is a strong focalization of the winds along the northeastern coast of Alicante province which drives the humid air mass through the coastal valleys to the mountains near the coast, thus enhancing the orographic trigger mechanism. Figure 13 shows equivalent potential temperature, vertical velocity and wind vectors in a W-E vertical cross-section at $38.8^{\circ}$ N. In Fig. 13a we can see an almost horizontal moist low-level easterly advection towards the coast. Some vertical motion arises just above the first coastal orographic barriers at 00:00 UTC on 12 October. $6 \mathrm{~h}$ later (Fig. 13b) a strong upward motion is located by RAMS just above the first significant elevations (close to $700 \mathrm{~m}$ ) from the coast, this vertical wind maxima is mainly due to the orographic triggering, along with some convergence lines at surface levels and the presence of instability in middle and upper layers; this vertical motion weakens but persists at 12:00 UTC on 12 October (Fig. 13c). The persistence of these motions, easterly moist advection plus vertical ascent, in addition to the presence of a cold air pool aloft (Fig. 10) favours the onset and persistence of heavy rains in the area.

With respect to the precipitation, let us look at the results of the inner grid (4) which is centered on the area where the rain event took place and has the highest spatial resolution. The accumulated precipitation calculated by RAMS model is shown in Fig. 14 for both days of the event and for the total 48-h accumulated values (panels a, b, and c). On 11 October 2007 RAMS correctly captures the rain area (Fig. 14a) located on Cape La Nao $\left(0-0.2^{\circ} \mathrm{E}\right.$ and $\left.38.7-38.9^{\circ} \mathrm{N}\right)$ but with somewhat lower values and with the precipitation peak displaced slightly to the north from the observed maximum. But RAMS also shows a larger rain area located along $39.0^{\circ} \mathrm{N}$ that was not present in the recorded data. Most of the precipitation occurred during the first $12 \mathrm{~h}$ of 12 October. The accumulated rain on 12 October calculated by RAMS model 

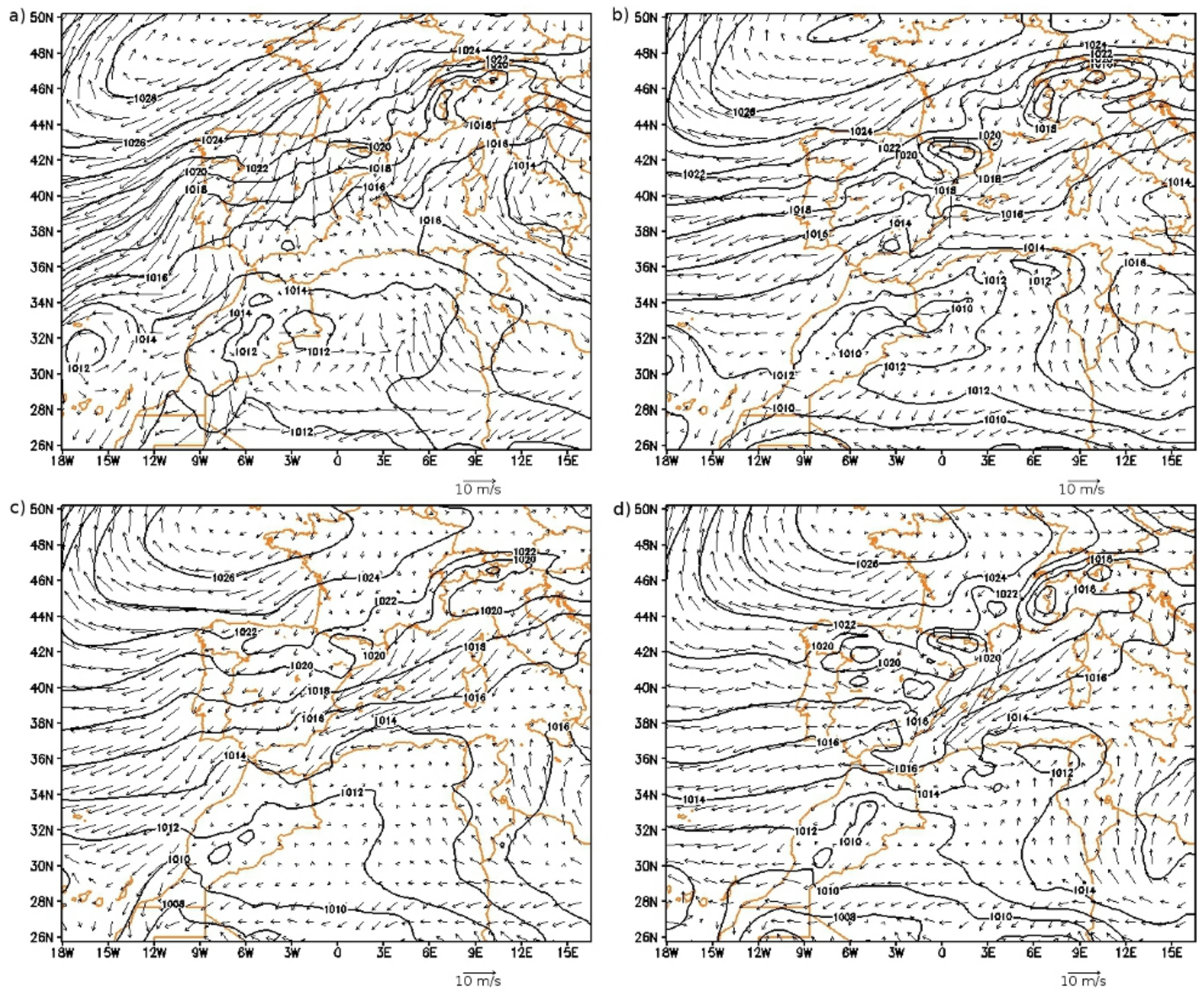

Fig. 11. RAMS model sea level pressure (hPa, solid line) and wind (arrows) for the control simulation at (a) 00:00 UTC 11 October, (b) 12:00 UTC 11 October, (c) 00:00 UTC 12 October, (d) 12:00 UTC 12 October.

is shown in Fig. 14b and it fits well with the recorded data. RAMS rainfall shows the actual rain area in northeastern Alicante province, with the largest rainfall amounts in an area inland and slightly to the west of Cape La Nao, in agreement with the observations. The two recorded maximum precipitation areas also appear in the RAMS results, but again the rainfall amounts are underestimated, showing a maximum lower than $300 \mathrm{~mm}$ when this value was in fact exceeded, as can be seen in Table 1. With regard to the total accumulated values for the whole event, i.e, the sum of both 11 and 12 October, RAMS captures well the spatial distribution of the rain but underestimates the precipitation values (compare Fig. 7b and Fig. 14c).
The quantitative evaluation of the precipitation is done by comparing forecast data against observed data. The temporal evolution of the rain simulated by RAMS has been checked against surface recorded data for three selected stations in the rain area. Accumulated and hourly rainfall intensity values, both forecast and observed, are shown in Fig. 14. From the comparison of observed and simulated rainfall it can be seen that RAMS correctly catches the initiation and ending times of the rain event for the 3 stations, as well as for other stations (not shown). However, RAMS fails to reproduce the intensity at the times when peak intensities were recorded. For the three stations, maximum precipitation intensity occurs 32 $36 \mathrm{~h}$ after the start of the simulation, and RAMS does not reproduce it well. As a consequence, RAMS total accumulated precipitation underestimates the observed quantities. 

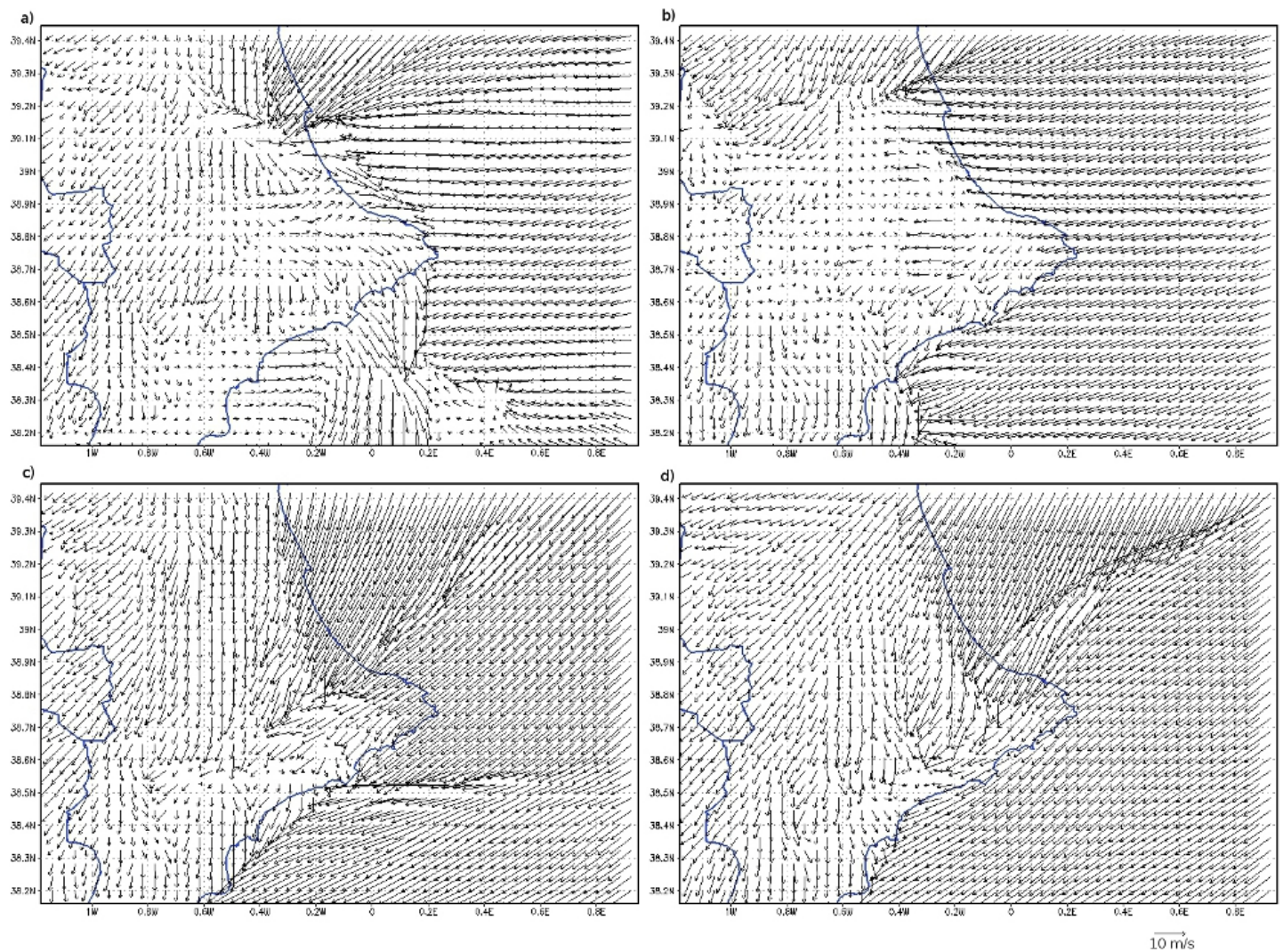

Fig. 12. RAMS model simulated wind field at surface (grid 4) for the control simulation on 11 October (a) 18:00 UTC and 12 October (b) 00:00 UTC, (c) 06h UTC, d)12:00 UTC.

\subsubsection{NOORO1 run}

A sensitivity test has been run to investigate the impact of local orography on the model results, especially in terms of the precipitation forecast. The RAMS simulation without orography within the rain area (NOORO1) uses the same grid specifications and RAMS physical settings as the CTRL run, except that orography has been completely removed (set to 0 ) from all model grids in the area corresponding to model grid 4.

The synoptic settings simulated by RAMS in the coarser model grid (not shown) are essentially the same as those obtained in the control run (Figs. 10 and 11), showing the easterly-northeasterly advection at low levels over the Mediterranean and the presence of a cold air pool above the Valencia region. Moving to higher spatial resolution (grid 4) in the rain area, the NOORO1 run shows very similar wind fields to those shown in Fig. 12 for the CTRL simulation. Only minor differences can be found, but in this case it is worth noting that at certain times in the simulation the maritime winds extend further inland than in the CTRL run.

NOORO1 shows a strong focalization of the winds along the northeastern coast of Alicante province, driving the humid air mass through the coast across model grid 4 . Figure 13
(W-E vertical cross-section at $38.8^{\circ} \mathrm{N}$ ) illustrates the advection of moist air from the sea that extends slightly farther inland than in the CTRL run. The vertical velocities presented in Fig. 13d) show a clear ascent close to the western boundary of model grid 4 at 00:00 UTC on 12 October where the air mass is influenced by the presence of the orography of the grid 3 domain, at the boundary between grids 3 and 4 . At 06:00 UTC (Fig. 13e) a stronger upward motion is located just above the rain area but it is clearly weaker than in the CTRL run and slightly displaced eastward, probably due to convergence of the maritime low level jet and the drier continental air mass and to the presence of instability at middle and upper levels. $6 \mathrm{~h}$ later, at 12:00 UTC on 12 October, the vertical velocity decreases and remains well below the values in the CTRL run (Fig. 13f).

The precipitation forecast by RAMS for both, CTRL and NOORO1, simulations is shown in Fig. 14; panels d, e, and $\mathrm{f}$ show the accumulated precipitation in the NOORO1 simulation. It can be seen that the forecast precipitation areas are weaker and displaced inland with respect to the CTRL run for both 11 and 12 October, and also for the 48-h accumulated precipitation. Moreover, NOORO1 produces only a narrow area of intense precipitation, while CTRL run forecasts several localized regions affected by heavy rainfall. 

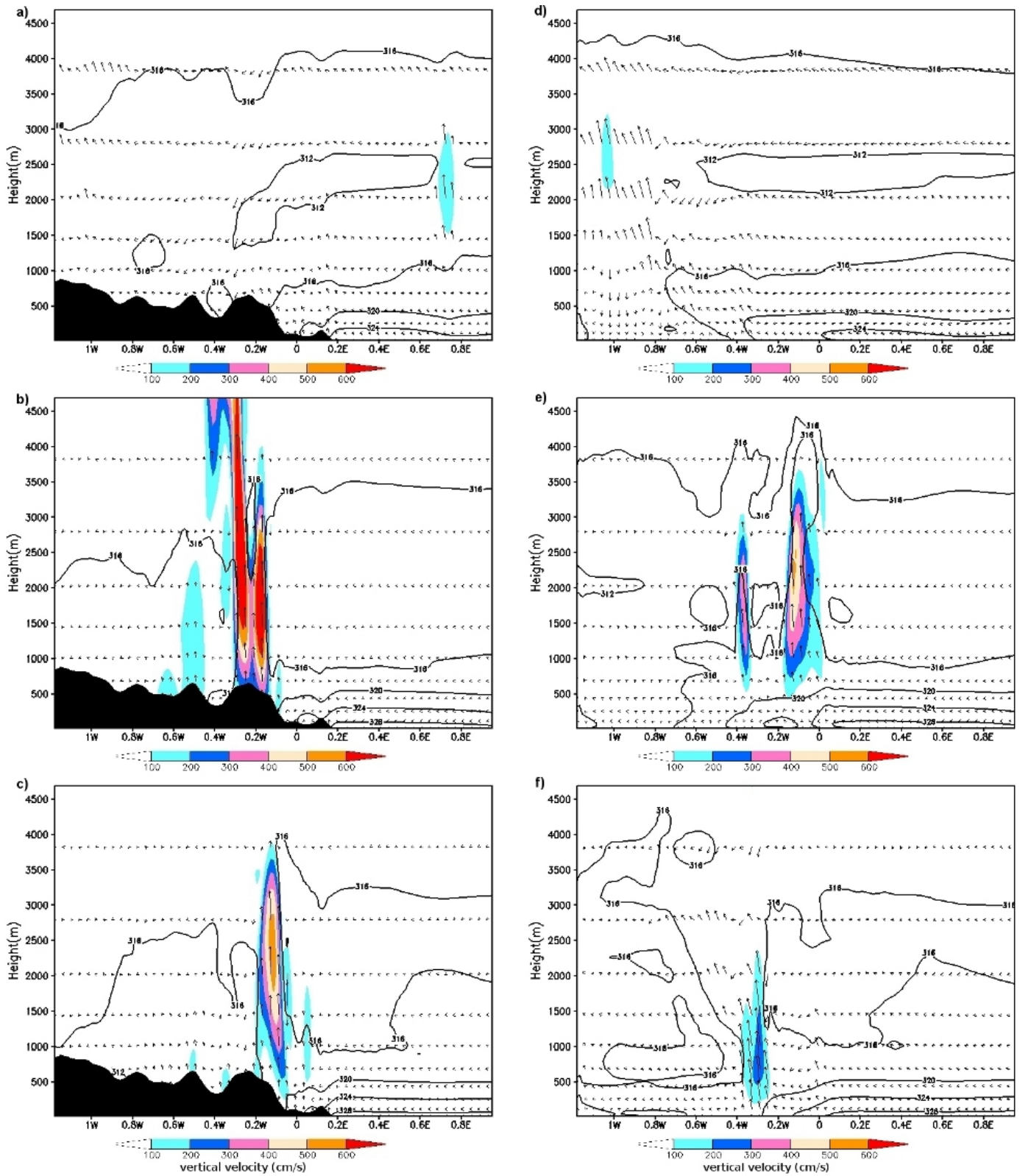

Fig. 13. Vertical cross section at $38.8^{\circ} \mathrm{N}$ RAMS equivalent potential temperature (K, contoured), vertical velocity (cm/s, shaded color) and wind vector (arrows) for CTRL simulation on: (a) 00:00 UTC 12 October, (b) 06:00 UTC 12 October and (c) 12:00 UTC 12 October 2007, and NOORO1 simulation (d) 00:00 UTC 12 October, (e) 06:00 UTC 12 October and (f) 12:00 UTC 12 October 2007.

\section{Conclusions}

The Valencia region is a propitious area for torrential rains, especially the northern part of Alicante province and the southern part of Valencia province. An extreme rain event took place on 11 and 12 October 2007 which caused extensive economic losses, damages to infrastructures and some human casualties. In this work we have described the synoptic environment of the event and the precipitation distribution, and then we have simulated the event by means of the meteorological model RAMS.
The general framework of the rain event studied in this paper is an easterly advection of cold(er) air over a warm(er) Mediterranean sea, in addition to the presence of a cold air pool aloft. This situation led to the arrival of a moist and potentially unstable air mass over the Valencian coast where it initiated an ascent due to orographic triggering. Then cloudiness developed at the coast and at the first orographic barriers near the coast, and the rainfall began, going from light to strong. The presence of an isolated low or colder air at upper levels enhanced the instability, providing propitious 



Fig. 14. RAMS accumulated precipitation (mm) for CTRL simulation on (a) 11 October, (b) 12 October and (c) 11-12 October 2007 and NOORO1 simulation (d) 11 October, (e) 12 October and (f) 11-12 October 2007.

conditions for the development of severe or mesoscale convective systems. The persistence of marine feedback, i.e., moisture feeding by maritime winds at low and mid levels, helped the precipitating system to stay stationary over the rain area for some hours producing both high intensity and high accumulated precipitation values. In previous works
(Millán et al., 1995; Pastor et al., 2001; Millán et al., 2005), the authors have identified this mechanism as the cause of torrential rains in the Valencia region.

In our case, the event was an extraordinary one with more than $400 \mathrm{~mm}$ of accumulated precipitation in less than $12 \mathrm{~h}$ in the northeastern area of Alicante province in the Valencia 

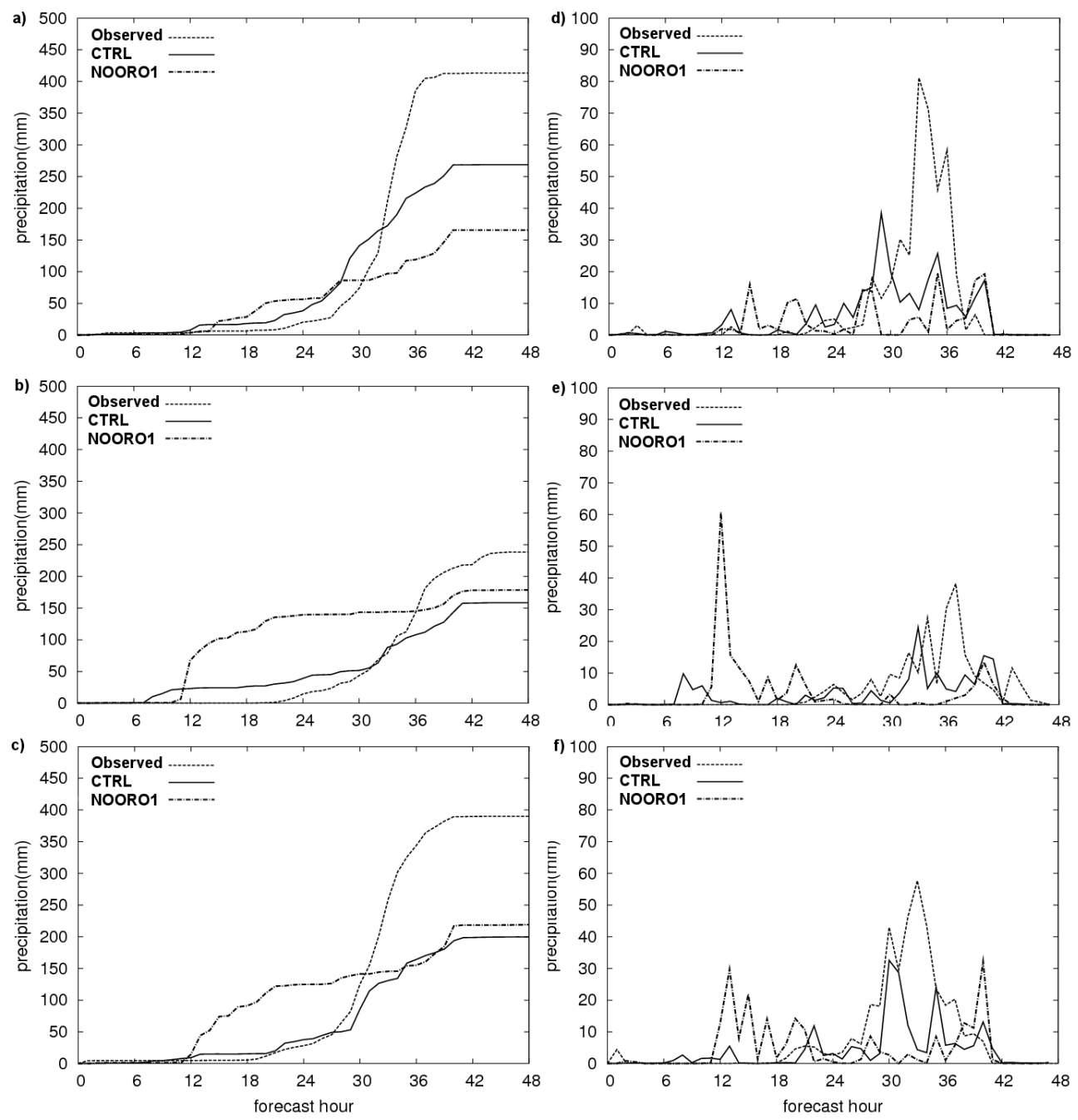

Fig. 15. Hourly evolution of observed (dashed line) vs. RAMS CTRL (solid line) and NOORO1 (dashed-dotted line) runs accumulated precipitation (mm) at (a) Gallinera, (b) Guadalest, and (c) Tollos and precipitation intensity in mm at (d) Gallinera, (e) Guadalest, and (f) Tollos.

region, on the Mediterranean coast of Spain. From our study of the NCEP/NCAR Reanalysis data, the synoptic settings responded to the theoretical framework previously explained. A long-track eastern advection through the Mediterranean was driven by an anticyclone located over Northern and Central Europe. When this persistent moisture advection met an upper-level isolated low moving south over the eastern Iberian Peninsula, heavy rains were generated in the Valencia region, especially in its central area. Surface observations show that strong precipitation lasted from $8-12 \mathrm{~h}$, starting late on 11 October, with the most intense rains concentrated in a $2-4 \mathrm{~h}$ period in the first hours of 12 October.

After characterizing the event, we have analysed it using the RAMS model output. RAMS well captures the synoptic settings, correctly locating the high pressures over northern and continental Europe with the anticyclone centered over Southern England and Northern France. At lower levels
RAMS shows the presence of an easterly to northeasterly wind flux that drives moisture towards the Spanish Mediterranean coast. At upper levels ( $500 \mathrm{hPa})$ RAMS successfully locates an isolated low over eastern Spain moving southward, although its evolution in RAMS simulation locates it over the Mediterranean sea some hours in advance with respect to what is shown by the NCEP/NCAR Reanalysis.

By looking at the inner grid, the one with highest spatial resolution $(1.5 \mathrm{~km})$, we have shown the wind affecting the study area in detail. Strong and persistent northeasterly winds reaching the coastal valleys and mountain chains near the coast were simulated. With this orography, the moisture feeding and the instability at upper levels, RAMS model reproduces the heavy rains in the study area. The spatial distribution of the rainfall is correctly determined by the model, which successfully locates the maximum precipitation area. Nevertheless, the results are not so satisfactory with respect 
to the amount of precipitation. RAMS mainly gives values between $150-250 \mathrm{~mm}$ in the area where recorded data are generally between $250-300 \mathrm{~mm}$. With respect to maximum values, RAMS well locates two small areas where 350 $400 \mathrm{~mm}$ (or higher) were recorded but it shows smaller values of 250 and $300 \mathrm{~mm}$, respectively.

Sensitivity tests have been run with the RAMS model to investigate the role of orography in the onset and development of the rain event by removing the orography in the area occupied by the inner model domain, corresponding to the rain area. Results from the control run show the presence of a strong updraft above the mountains close to the coast in the rain area. This ascent becomes less important in the simulation in which orography is removed in the area corresponding to the inner model grid, the one with the highest spatial resolution and located just above the rain area. Moreover, it is slightly displaced eastward with respect to the control run. In this experiment, RAMS forecast does not present several heavy precipitation areas close to the coast as in the control run. Moreover, rainfall is increased inland close to the western boundary of the domain, where the flow is influenced by the orography of the grid 3 domain. On the basis of these results, the orography of the area appears to be a key factor in the rain event, acting as a trigger mechanism to start the convection process leading to heavy rainfall and conditioning the location of the rain area.

This paper is intended as a first approach to an extraordinary rain event registered in the Valencia region. Its synoptic and modelling description will permit a better knowledge of the mesoscale convective systems and the mechanisms driving torrential rains in the Western Mediterranean. After having determined the important effect of orography in this heavy rainfall event, we are currently conducting model sensitivity tests to analyze the influence of different cumulus parametrizations for the same event. Future work will investigate the role of sea surface temperature and latent and sensible heat fluxes in the development of the rain event. This work could help to develop better forecasting systems to prevent the high social and economic impact heavy rains produce in Mediterranean countries.

Acknowledgements. This work has been funded by the Spanish Ministerio de Educación y Ciencia through the projects NIEVA CGL2008-04550/CLI, CONSOLIDER-INGENIO 2010 (Proyecto GRACCIE) CSD2007-00067 and the EU-funded Integrated Project CIRCE (Project. No. 036961).

QuikScat data are produced by Remote Sensing Systems and sponsored by the NASA Ocean Vector Winds Science Team. Data are available at www.remss.com. FNL data used for RAMS initialization are from the Research Data Archive (RDA) which is maintained by the Computational and Information Systems Laboratory (CISL) at the National Center for Atmospheric Research (NCAR). NCAR is sponsored by the National Science Foundation (NSF). The original data are available from the RDA (http://dss.ucar.edu) in dataset number ds083.2.
We also want to thank the reviewers, whose comments and suggestions have greatly improved the paper, and Jackie Scheiding for the translation and review of the text.

Edited by: A. Mugnai

Reviewed by: three anonymous referees

\section{References}

Alpert, P., Ben-Gai, T., Baharad, A., Benjamini, Y., Yekutieli, D., Colacino, M., Diodato, L., Ramis, C., Homar, V., Romero, R., Michaelides, S., and Manes, A.: The paradoxical increase of Mediterranean extreme daily rainfall in spite of decrease in total values, Geophys. Res. Lett., 29, 31-1, doi:10.1029/ 2001GL013554, 2002.

Anderson, J. R., Hardy, E. E., Roach, J. T., and Witmer, R. E.: A land use and land cover classification system for use with remote sensor data, Government Printing Office, Washington DC, Tech. rep., U.S. Geological Survey Professional Paper 964, 1976.

Armengot, R.: Las Lluvias Intensas en la Comunidad Valenciana, Centro de Publicaciones, Secretaría General Técnica, Ministerio de Medio Ambiente, 2002.

Bluestein, H. B.: Observations and Theory of Weather Systems, vol. 2, Synoptic-Dynamic Meteorology in Midlatitudes, Oxford University Press, 1993.

Bresson, R., Ricard, D., and Ducrocq, V.: Idealized mesoscale numerical study of Mediterranean heavy precipitating convective systems, Meteorol. Atmos. Phys., 103, 45-55, doi:10.1007/ s00703-008-0338-z, 2009.

Chen, C. and Cotton, W.: A One-Dimensional Simulation of the Stratocumulus-Capped Mixed Layer, Bound.-Lay. Meteorol., 25, 289-321, 1983.

Cotton, W. R., Pielke, R. A., S., Walko, R. L., Liston, G. E., Tremback, C. J., Jiang, H., McAnelly, R. L., Harrington, J. Y., Nicholls, M. E., Carrio, G. G., and McFadden, J. P.: RAMS 2001: Current status and future directions, Meteorol. Atmos. Phys., 82, 5-29, 2003.

Davolio, S., Miglietta, M. M., Moscatello, A., Pacifico, F., Buzzi, A., and Rotunno, R.: Numerical forecast and analysis of a tropical-like cyclone in the Ionian Sea, Nat. Hazards Earth Syst. Sci., 9, 551-562, doi:10.5194/nhess-9-551-2009, 2009.

Elías, F. and Ruiz, L.: Precipitaciones Máximas en España, ICONA, 1979.

Estrela, M., Millán, M., Peñarrocha, D., and Pastor, F.: De la Gota Fría al Frente de Retroceso, Centro Francisco Tomás y Valiente, UNED Alzira-Valencia Fundación CEAM, 2002 (in Spanish).

Estrela, M., Pastor, F., and Millán, M.: Air Mass Change along Trajectories in the Western Mediterranean Basin in the Torrential Rain Events in the Valencia Region, in: Mediterranean Storms, CD of Proceedings of the 4th EGS Plinius Conference 2002 (ISBN: 84-7632-792-7), 2003.

Estrela, M., Pastor, F., Miró, J., Gómez, I., and Barberá, M.: Heat waves prediction system in a Mediterranean area (Valencia region), in: 7th EMS Annual Meeting/8th European Conference on Applications of Meteorology, 2007.

Federico, S., Avolio, E., Bellecci, C., Lavagnini, A., Colacino, M., and Walko, R. L.: Numerical analysis of an intense rainstorm occurred in southern Italy, Nat. Hazards Earth Syst. Sci., 8, 1935, doi:10.5194/nhess-8-19-2008, 2008. 
Glickman, T. (Ed.): Glossary of Meteorology, American Meteorological Society, 2000.

Horvath, K., Fita, L., Romero, R., Ivancan-Picek, B., and Stiperski, I.: Cyclogenesis in the lee of the Atlas Mountains: a factor separation numerical study, Adv. Geosci., 7, 327-331, doi:10.5194/adgeo-7-327-2006, 2006.

Jansa, A., Genoves, A., Picornell, M., Campins, J., Riosalido, R., and Carretero, O.: Western Mediterranean cyclones and heavy rain. Part 2: Statistical approach, Meteorol. Appl., 8, 43-56, 2001.

Kalnay, E. and Coauthors: The NCEP/NCAR 40-Year Reanalysis Project, B. Am. Meteorol. Soc., 77, 437-471, 1996.

Lebeaupin, C., Ducrocq, V., and Giordani, H.: Sensitivity of torrential rain events to the sea surface temperature based on highresolution numerical forecasts, J. Geophys. Res.-Atmos., 111, 12110-12110, 2006.

Lebeaupin, C., Ducrocq, V., and Giordani, H.: Two-way onedimensional high-resolution airsea coupled modelling applied to Mediterranean heavy rain events, Q. J. Roy. Meteorol. Soc., 135, 187-204, doi:10.1002/qj.338, 2009.

Mellor, G. and Yamada, T.: Development of a Turbulence Closure Model for Geophysical Fluid Problems, Rev. Geophys., 20, 851875, 1982.

Meneguzzo, F., Pasqui, M., Messeri, G., and Rossi, M.: Highresolution simulation of a deep Mediterranean cyclone using RAMS model, Proc. Second EGS Plinius Conf. on Mediterranean Storms, Siena, Italy, EGS, 225-235, 2000.

Meneguzzo, F., Menduni, G., Maracchi, G., Zipoli, G., Gozzini, B., Grifoni, D., Messeri, G., Pasqui, M., Rossi, M., and Tremback, C. J.: Explicit forecasting of precipitation: sensitivity of model RAMS to surface features, microphysics, convection, resolution, in: Mediterranean Storms, 3rd Plinius Conference, edited by: Deidda, R., Mugnai, A., and Siccardi, F., GNDCI Publ. N. 2560, ISBN: 88-8080-031-0, 79-84, 2001.

Meneguzzo, F., Pasqui, M., Menduni, G., Messeri, G., Gozzini, B., Grifoni, D., Rossi, M., and Maracchi, G.: Sensitivity of meteorological high-resolution numerical simulations of the biggest floods occurred over the Arno river basin, Italy, in the 20th century, J. Hydrol., 288, 37-56, doi:10.1016/j.jhydrol.2003.11.032, available at: http://www.sciencedirect.com/science/article/ B6V6C-4BS0FVN-2/2/cec126252e1ca4b77d7c89403794e227, 2004.

Miglietta, M. M. and Regano, A.: An observational and numerical study of a flash-flood event over south-eastern Italy, Nat. Hazards Earth Syst. Sci., 8, 1417-1430, doi:10.5194/nhess-8-1417-2008, 2008.

Millán, M., Estrela, M. J., and Caselles, V.: Torrential Precipitations on the Spanish East Coast: The role of the Mediterranean Sea Surface Temperature, Atmos. Res., 36, 1-16, 1995.

Millán, M., Estrela, M. J., and Miró, J.: Rainfall Components: Variability and Spatial Distribution in a Mediterranean Area (Valencia Region), J. Climate, 18, 2682-2705, 2005.

Molinari, J.: A General Form of Kuo's Cumulus Parameterization, Mon. Weather Rev., 113, 1411-1416, 1985.

Palau, J. L., Pérez-Landa, G., Diéguez, J. J., Monter, C., and Millán, M. M.: The importance of meteorological scales to forecast air pollution scenarios on coastal complex terrain, Atmos. Chem. Phys., 5, 2771-2785, doi:10.5194/acp-5-2771-2005, 2005.
Pastor, F., Estrela, M. J., Peñarrocha, D., and Millán, M. M.: Torrential rains on the Spanish Mediterranean coast: Modeling the effects of the sea surface temperature, J. Appl. Meteorol., 40, 1180-1195, 2001.

Peñarrocha, D., Estrela, M. J., and Millán, M.: Classification of daily rainfall patterns in a Mediterranean area with extreme intensity levels: The Valencia region, Int. J. Climatol., 22, 677695, 2002.

Pérez Cueva, A. (Ed.): Atlas Climàtic de la Comunitat Valenciana, Generalitat Valenciana, Conselleria d'Obres Publiques, Urbanisme i Transports, 1994 (in Valencian).

Pérez Cueva, A. and Armengot, R.: El Temporal de Octubre de 1982, Cuadernos de Geografía, la Riada del Júcar (Octubre 1982), 1983 (in Spanish).

Pérez-Landa, G., Ciais, P., Gangoiti, G., Palau, J. L., Carrara, A., Gioli, B., Miglietta, F., Schumacher, M., Millán, M. M., and Sanz, M. J.: Mesoscale circulations over complex terrain in the Valencia coastal region, Spain - Part 2: Modeling $\mathrm{CO}_{2}$ transport using idealized surface fluxes, Atmos. Chem. Phys., 7, 18511868, doi:10.5194/acp-7-1851-2007, 2007a.

Pérez-Landa, G., Ciais, P., Sanz, M. J., Gioli, B., Miglietta, F., Palau, J. L., Gangoiti, G., and Millán, M. M.: Mesoscale circulations over complex terrain in the Valencia coastal region, Spain Part 1: Simulation of diurnal circulation regimes, Atmos. Chem. Phys., 7, 1835-1849, doi:10.5194/acp-7-1835-2007, 2007b.

Pielke, R., Cotton, R., Walko, R., Tremback, C., Lyons, W., Grasso, L., Nicholls, M., Moran, M., Wesley, D., Lee, T., and Copeland, J.: A Comprehensive Meteorological Modelling System - RAMS, Meteorol. Atmos. Phys., 49, 69-91, 1992.

Romero, R., Ramis, C., and Alonso, S.: Numerical simulation of an extreme rainfall event in Catalonia: Role of orography and evaporation from the sea, Q. J. Roy. Meteor. Soc., 123, 537-559, 1997.

Romero, R., Guijarro, J. A., Ramis, C., and Alonso, S.: A 30-year (1964-1993) daily rainfall data base for the Spanish Mediterranean regions: First exploratory study, Int. J. Climatol., 18, 541-560, doi:10.1002/(SICI)1097-0088(199804)18:5/541:: AID-JOC270〉3.0.CO;2-N, 1998.

Salvador, R., Calbó, J., and Millán, M.: Horizontal Grid Size Selection and its Influence on Mesoscale Model Simulations, J. Appl. Meteorol., 39, 1311-1329, 1999.

Solomon, S., Qin, D., Manning, M., Chen, Z., Marquis, M., Averyt, K. B., Tignor, M., and Miller, H. L. (Eds.): The Physical Science Basis, in: Intergovernmental Panel on Climate Change (IPCC): Climate Change 2007, Cambridge University Press, Cambridge, UK and New York, NY, USA, 2007.

Walko, R. L., Cotton, W. R., Meyers, M. P., and Harrington, J. Y.: New RAMS cloud microphysics parameterization. Part I: The single-moment scheme, Atmos. Res., 38, 29-62, 1995.

Walko, R. L., Band, L. E., Baron, J., Kittel, T. G. F., Lammers, R., Lee, T. J., Ojima, D., Pielke Sr., R. A., Taylor, C., Tague, C., Tremback, C. J., and Vidale, P. L.: Coupled atmosphericbiophysics-hydrology models for environmental modeling, J. Appl. Meteorol., 39, 931-944, 2000. 